\title{
Perbaikan Tata Letak Gudang Produk Setengah Jadi CV Harapan Baru Menggunakan Metode Class Based Storage
}

\author{
Ardacandra Faisal Pinasthika ${ }^{1)}$, Eva Kholisoh ${ }^{2)}$, Nur Azizah Rahmadani ${ }^{3)}$ \\ ${ }^{1), 2), 3)}$ Program Studi SarjanaTeknikIndustri, FakultasTeknik, UniversitasSebelasMaret \\ Jl. Ir. Sutami 36A Surakarta 57126 Indonesia
}

\begin{abstract}
Abstracs
CV Harapan Baru is a company engaged in the field of printing. In the warehouse, there is a warehouse for raw materials and warehouse for semi-finished products. After printing, semi-finished products are taken by the publisher and the publisher entered into a binder. In observations of allocating semi-finished products, company conducts random storage that resulting length of the operator in making semi-finished products to be distributed to publishers. Therefore, the repairs warehouse layout semi-finished product using Based Storage Class Method to be effective in making decision. In this study, the Class Storage Based method in the placement of semi-finished products made of grouping based on the book publisher. With this method, the operator can perform retrieval semi-finished products with ease and warehouse cleanly. The improvement warehouse layout can reduce material handling costs which originally amounted $\mathrm{Rp} 300,000,000.00$ to $\mathrm{Rp} 202,488,104.00$ per year.
\end{abstract}

Keywords : Semi-Finished Products, Class Based Storage, Warehouse, LKS, Printing.

\section{Pendahuluan}

CV Harapan Baru yang berlokasi di Ceplukan RT 01/XVI, Wonorejo, Gondangrejo, Karanganyarmerupakan perusahaan yang bergerak dalam bidang percetakan. Perusahaan ini melakukan produksi berdasarkan order. Produk utama CV Harapan Baru Karanganyar yaitu buku LKS (Lembar Kerja Siswa) untuk SD sampai dengan SMA/SMK yang belum dilakukan penjilidan. Hal ini dikarenakan kebijakan perusahaan yang tidak mempunyai mesin jilid sendiri. Jadi, produk yang dihasilkan CV Harapan Baru masih berupa produk setengah jadi yang nantinya akan diambil oleh penerbit dan penerbitnya sendiri yang akan melakukan pemesanan penjilidan.

Secara garis besar CV Harapan baru terdiri dari 2 bagian yaitu bagian produksi dan bagian gudang. Gudang yang dimiliki perusahaan ini hanya terdapat 2 gudang yaitu gudang untuk bahan baku dan gudang untuk produk setengah jadi. Dalam melakukan penyimpanan barang digudang CV Harapan Baru melakukannya secara random/acak. Hasil akhir dari bagian produksi masuk ke gudang langsung di tempatkan secara acak tanpa aturan tertentu. Selain itu juga terdapat hasil akhir dari produksi yang masih ditempatkan dibagian produksi. Hal ini terjadi karena tidak adanya sistem alokasi/ penempatan barang yang tetap dan kurang jelasnya batasan area penyimpanan. Sistem alokasi penyimpanan barang secara random/acak tersebut menyebabkan letak barang berubah-ubah setiap kali hasil dari bagian produksi masuk ke gudang.

Penempatan yang dilakukan secara acak tersebut menyebabkan operator kesulitan dalam melakukan identifikasi dan proses pengambilan produk. Jadi harus memerlukan waktu yang lebih untuk mencari produk mana yang akan diambil. Selain itu juga kurangnya pemanfaatan kapasitas gudang sebenarnya. Oleh karena itu perlu dilakukan perbaikan tata letak gudang agar operator mudah dalam melakukan pengambilan barang di gudang tanpa perlu mencari dalam waktu yang lama selain itu gudang juga tertata rapi dan tidak terkesan sempit. Dari berbagai permasalahan yang ditemukan di lapangan tersebut dapat diketahui faktor yang menyebabkan waktu yang dibutuhkan operator dalam pengambilan produk menjadi lama antara lain dari faktor manusia (man) yaitu operator tidak meletakkan produk setengah jadi dengan tepat, hal itu 
disebabkan karena operator tidak mengetahui adanya metode penembatan barang. Faktor yang kedua yaitu faktor metode (method) antara lain dari segi penataan produk setengah jadi yang berantakan di warehouse dan terdapat juga yang berada di area produksi, hal ini disebabkan karena dalam penataan produk setengah jadi tidak dilakukan pengelompokkan. Selain itu dari faktor metode belum terdapat kebijakan mengenai penyimpanan produk setengah jadi.

Untuk mengatasi dan meminimalisir permasalahan tersebut maka dilakukan penelitian dengan merancang perbaikan tata letak gudang produk setengah jadi dengan meggunakan Metode Class Based Storage. Metode ini digunakan dalam perbaikan tata letak gudang produk setengah jadi di CV Harapan Baru Karanganyar dengan pertimbangan produk akhir yang dihasilkan dari bagian produksi dalam penyimpanannya dikelompokkan berdasarkan penerbit yang melakukan pemesanan. Jadi jika penerbit datang untuk melakukan pengambilan produk setengah jadi tersebut langsung dapat ditemukan dengan mudah mana yang harus diambil tanpa perlu dilakukan pencarian yang membutuhkan waktu yang lama.

Dalam penelitian di CV Harapan Baru Karanganyar ini permasalahan dibatasi pada :

1. Penelitianhanyadilakukanpadagudangproduksetengahjadi

2. Penelitianfokuspadapelanggantetap (penerbit)

3. Pengambilan data berdasarkan rata-rata produksitiappemesanannya

Pengelompokkanproduksetengahjadiberdasarkanpenerbit (pelanggan yang memesan)

\section{Metode Penelitian}

Berikut merupakan metodologi yang dilakukan dalam penelitian. Dalam mengidentifikasi permasalahan perlu melakukan studi literatur untuk mengetahui terlebih dahulu mengenai pergudangan san studi lapangan untuk mengetahui informasi yang berkaitan dengan pergudangan di CV Harapan Baru Karanganyar secara langsung. Studi lapangan berupa wawancara dengan manajer bagian pergudangan dan observasi langsung ke pergudangannya. Selanjutnya diketahui permasalahan apa yang perlu untuk dilakukan perbaikan. Langkah selanjutnya yaitu dilakukan pengumpulan data berupa dimensi pallet, kapasitas pallet, ukuran gudang produk setengah jadi, jumlah produk setengah jadi yang disimpan di gudang, dan kebijakan yang diterapkan dalam menempatkan barang, dan data pemesanan tiap penerbit. Selanjutnya dilakukan pengolahan dari data yang sudah dikumpulkan tersebut. Pengolahan data berupa pengalokasian produk setengah jadi yang disesuaikan dengan kapasitas pallet dan kapasitas gudang, yang selanjutnya didapatkan usulan layout yang sudah dilakukan perbaikan. Kemudian dari hasil pengolahan data dilakukan analisis dan dapat diambil kesimpulan

\section{Hasil dan Pembahasan}

Tata letak Gudang Produk Setengah Jadi

Berikut merupakan tata letak gudang produk setengah jadi di CV Harapan Baru Karanganyar.

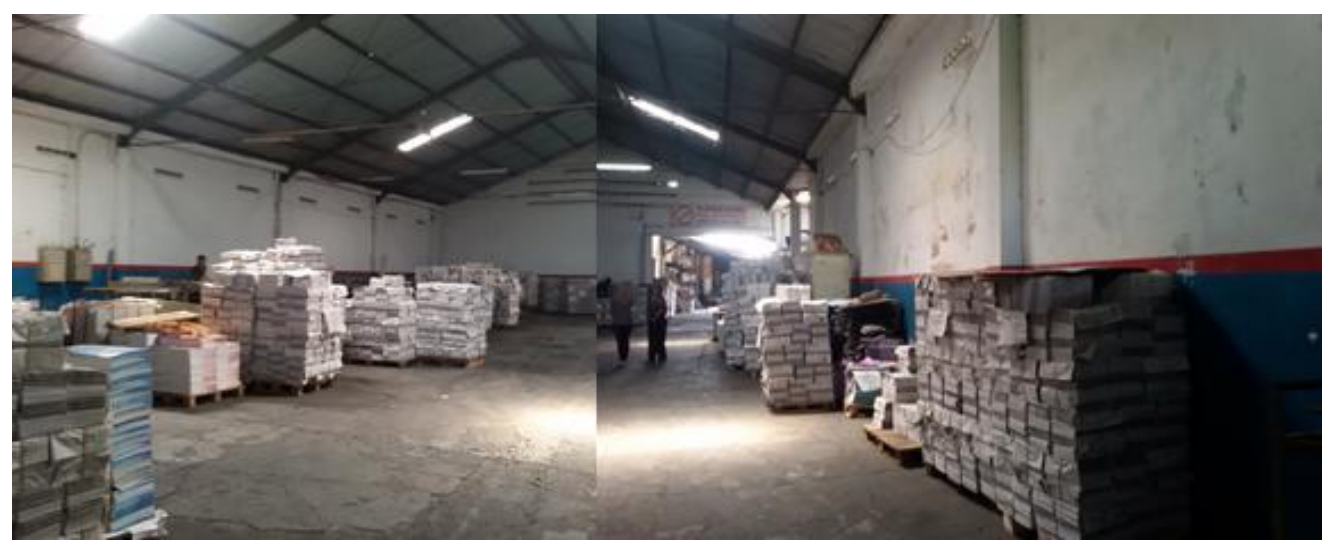

Gambar 1. Gudang Produk Setengah Jadi 
a Permasalahan di Gudang Produk Setengah Jadi

Terdapat berbagai permasalahan yang ada di gudang produk setengah jadi yang membuat gudang tidak teratur dan kesulitan pekerja dalam mencari jenis produk setengah jadi tersebut karena penataannya yang sembarangan.

a. TerdapatMesinPenjilidan yang tidakterpakai di gudangproduksetengahjadi

b. Terdapatmesincetak cover di gudangproduksetengahjadi

c. Terdapatsisakertashasilpemotongangudangproduksetengahjadi

d. Produksetengahjadidiletakkansecaraacak,

belumdisesuaikandenganjenisnyasehinggamenyulitkanpencarian

b Gambaran Layout Secara Keseluruhan

Berikut merupakan layout keseluruhan CV. Harapan baru dimana gudang produk setengah jadi ditunjukkan dengan area $\mathrm{A}$.
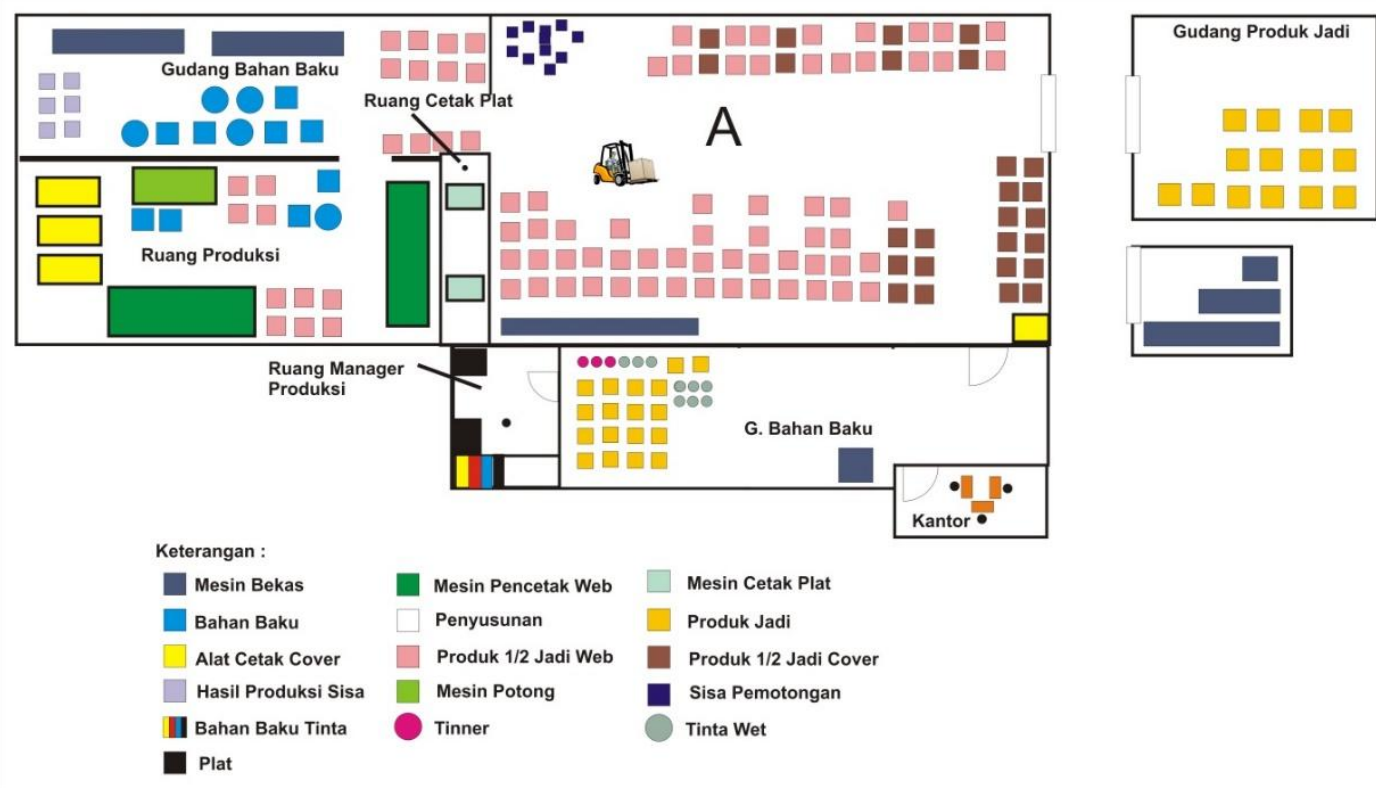

Gambar 8. Layout keseluruan CV Harapan Baru Karanganyar

Dari layout perusahaan, dapat dilihat bahwa penempatan produk setengah jadi tidak teratur (ditunjukkan dengan kotak warna pink), dimana ada space kosong maka dapat digunakan untuk tempat penyimpanan. Produk setengah jadi tidak hanya diletakkan di gudang produk setengah jadi saja, banyak produk yang diletakkan disembarang tempat dan diletakkan di ruang produksi. Hal ini tentu saja membuat pekerja mengalami kesulitan dalam mengidentifikasi dan mencari jenis produk setengah jadi tersebut. Kesulitan tersebut akan berdampak pada lamanya waktu untuk mencari. Sehingga usulan yang diberikanya itu melakukan perbaikan dengan mengelompokkan produk setengah jadi sesuai jenis penerbitnya.

\section{Informasi Umum}

\section{Karakteristik Kertas}

Produk setengah jadi yang disimpan digudang produk setengah jadi CV. Harapan Baru secara garis besar terdapat 2 jenis kertas yaitu kertas web (isi) dan kertas cover. Kertas tersebut disimpan di dalam gudang disusun dalam palet. Setiap palet berukuran $1 \mathrm{~m}$ x $1 \mathrm{~m}$. Dalam penyimpanannya kertas web (isi) dan cover tidak memiliki perlakuan khusus. Kedua jenis kertas tersebut diletakkan di sembarang tempat yang tersedia.

Untuk mendukung material handling dalam pemindahan produk setengah jadi dibutuhkan forklift berukuran $3,1 \mathrm{~m} \mathrm{x} \mathrm{1,2} \mathrm{m.}$ 


\section{Data Pemesanan Customer Per Semester}

Customer CV. Harapan Baru merupakan grup penerbit sendiri yaitu penerbit Tri Manunggal (TM), penerbit Harapan Baru (HB), penerbit Belajar Praktis (BP), dan penerbit Indonesia Jaya. Berikut merupakan data pemesanan dari penerbit tiap semester.

\section{Penerbit Tri Manunggal (TM)}

Data Pemesanan Penerbit Tri Manunggal untuk jenis buku yaitu buku LKS PKn, IPA, IPS, Bahasa Indonesia, Matematika, PAI, dan Wibowo untuk masing-masing kelas 1 sampai 6 SD adalah total 726600 buah.

\section{Penerbit Harapan Baru (HB)}

Data Pemesanan Penerbit Harapan Baru untuk jenis buku yaitu buku LKS PKn, Bahasa Indonesia, Matematika, Bahasa Inggris, TIK, SPK, Penjaskes, BK, Bahasa Jawa, Seni Rupa, IPS Terpadu, dan IPA untuk masing-masing kelas 7, 8, 9 SMP adalah total 640800 buah.

3. Penerbit Belajar Praktis (BP)

Data Pemesanan Penerbit Belajar Praktis untuk jenis buku yaitu buku LKS PKn, Bahasa Indonesia, Matematika, IPA, IPS, Bahasa Inggris, dan PAI untuk masing-masing kelas 1 sampai 6 SD adalah total 600600 buah.

\section{Penerbit Indonesia Jaya}

Data Pemesanan Penerbit Indonesia Jaya untuk jenis buku yaitu buku LKS IPA, Matematika, dan PKn untuk masing-masing kelas 1 sampai 6 SD adalah total 748800 buah, untuk kelas 7,8,9 SMP adalah total 374400 buah, dan untuk kelas 10,11,12 SMA dengan total 374400 buah.

\section{Jumlah In/Out Produk Setengah Jadi}

Dalam sehari, CV. Harapan Baru memproduksi Cetak Web dan Cetak Cover sebesar 55000 unit. Sehingga produk setengah jadi yang masuk kegudang adalah 55000 per hari. Sedangkan untuk jumlah produk yang keluar dari gudang produk setengah jadi dilakukan setiap memenuhi maksimal pengiriman dalam truk.

\begin{tabular}{|l|rlll|}
\hline Panjang Truk & $6,5 \mathrm{~m}$ & $\sim$ & 6 & $\mathrm{~m}$ \\
\cline { 1 - 1 } Lebar & $2,5 \mathrm{~m}$ & $\sim$ & 2 & $\mathrm{~m}$ \\
\cline { 1 - 1 } Tinggi & $2,2 \mathrm{~m}$ & $\downarrow$ & \\
\cline { 1 - 1 } Luas & $16,25 \mathrm{~m}$ & $12 \mathrm{~ms}$ & \\
\hline
\end{tabular}

Sehingga setiap produksi sudah memenuhi 12 palet maka produk setengah jadi akan keluar gudang. Dalam 1 susunan truk terdapat 12 palet cetak web (isi) dan 6 tumpuk cover. Pemenuhan 12 palet berdasarkan data pemesanan dari penerbit membutuhkan waktu 3 hari untuk produk setengah jadi sejumlah 12 palet keluar dari gudang.

\section{Penentuan Banyak Palet yang Dibutuhkan}

Untuk menentukan kebutuhan palet, diperlukan berapa lks maksimum yang dapat disusun dalam 1 palet. Berikut merupakan perhitungan untuk mencari maksimum lks yang dapat disusun dalam 1 palet:

Tabel 5. Data Perhitungan Maksimum LKS

\begin{tabular}{|l|c|c|c|c|}
\hline \multicolumn{1}{|c|}{ Jenis Kertas } & Web (Isi) & Satuan & $\begin{array}{c}\text { Cover } \\
(\mathbf{m})\end{array}$ & Satuan \\
\hline Panjang Kertas & 0,3 & $\mathrm{~m}$ & 0,4 & $\mathrm{~m}$ \\
\hline Lebar Kertas & 0,2 & $\mathrm{~m}$ & 0,3 & $\mathrm{~m}$ \\
\hline Tebal Kertas & 0,003 & $\mathrm{~m}$ & 0,0001 & $\mathrm{~m}$ \\
\hline Luas Kertas & 0,06 & $\mathrm{~m} 2$ & 0,12 & $\mathrm{~m} 2$ \\
\hline Susunan Kertas dalam 1 Palet & 17 & Unit & 9 & Unit \\
\hline Tinggi Susunan dalam 1 palet & 667 & Tingkat & 20000 & Tingkat \\
\hline Maksimal Banyak dalam 1 palet & 11339 & Unit & 180000 & Unit \\
\hline
\end{tabular}

Perhitungan Maksimum LKS dalam 1 palet untuk web (isi)

Maks LKS $($ Web) $=$ Susunan kertas 1 palet (unit) $x$ Tinggi Susunan 1 Palet (tingkat) 
Maks LKS $($ Web $)=17$ unit $x 667$ tingkat

Maks LKS $($ Web $)=11339$ unit

Perhitungan Maksimum LKS dalam 1 palet untuk cover

Maks LKS $($ Cover $)=$ Susunan kertas 1 palet (unit) $x$ Tinggi Susunan 1 Palet (tingkat)

Maks LKS (Cover) $=9$ unit $x 20000$ tingkat

Maks LKS (Cover) $=180000$ unit

Berdasarkan data pemesanan dari penerbit untuk setiap jenis lksnya, dapat ditentukan jumlah palet yang dibutuhkan untuk memenuhi pesanan penerbit yaitu sebagai berikut:

Tabel 6. Data Kebutuhan Palet

\begin{tabular}{|c|c|c|}
\hline \multirow{2}{*}{ Penerbit } & \multicolumn{2}{|c|}{ Kebutuhan (Pallet) } \\
\hline \multirow{2}{*}{ Indonesia Jaya } & \multirow{2}{*}{144} & 72 \\
\cline { 2 - 2 } & & 36 \\
\cline { 2 - 2 } & \multicolumn{2}{|c|}{84} \\
\hline TM & \multicolumn{2}{|c|}{72} \\
\hline HB & 84 \\
\hline BP
\end{tabular}

Tata letak Gudang Produk Setengah Jadi Usulan

1. Pemindahan Mesin Penjilidan dan Mesin Cetak Cover serta Sisa Kertas Keluar dari Gudang Produk Setengah Jadi

Mesin Jilid yang tidak terpakai yang berada di dalam gudang produk setengah jadi dipindahkan ke area mesin-mesin tidak terpakai. Mesin cetak cover dipindahkan dekat dengan mesin cetak cover lainnya di area produksi. Sisa kertas hasil pemotongan diletakkan di gudang mesin tidak terpakai dekat dengan gudang produk jadi.

\section{Kebutuhan Luas PenyimpanandalamGudangProdukSetengahJadi}

Berdasarkan jumlah produk yang masuk dan keluar dari gudang setiap harinya maka kebutuhan luas penyimpanan dalam gudang produk setengah jadi adalah sebagai berikut:

a. Kebutuhan Ruang untuk Produk Setengah Jadi Web (isi)

Berikut merupakan kebutuhan ruang untuk produk setengah jadi web (isi) apabila semua produk yang dipesan dari customer sudah diproduksi dan disimpan di dalam gudang.

Tabel 7. Data Kebutuhan Ruang Produk Setengah Jadi Web

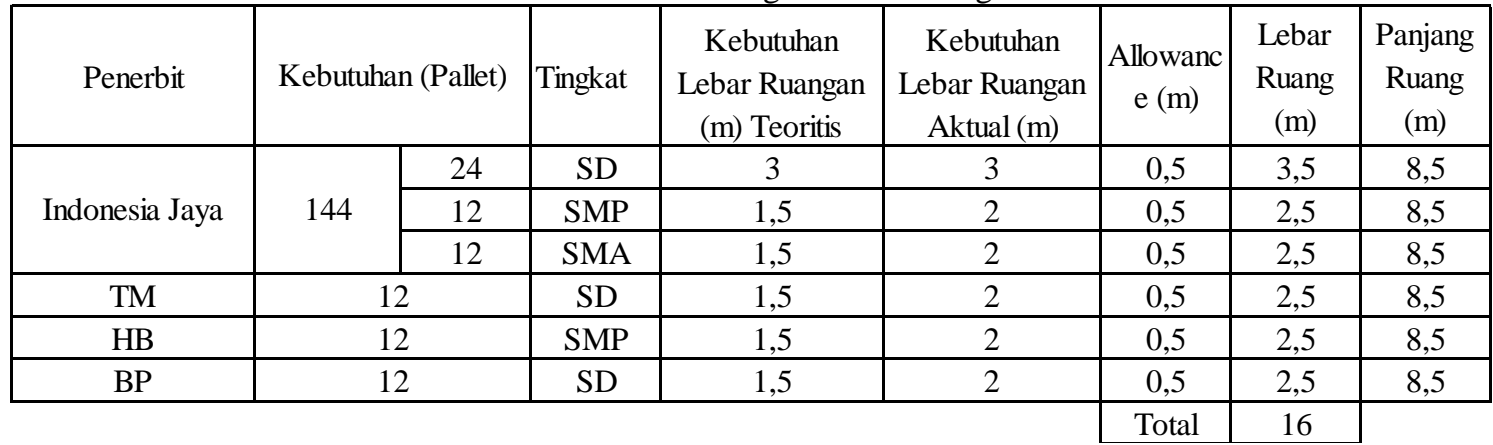

b. Kebutuhan Ruang untuk Produk Setengah Jadi Cover Keseluruhan Cover disusun dapat palet berdasarkan perhitungan sebagai berikut: 
Ukuran Cover LKS $20 \times 30$ penyusunan

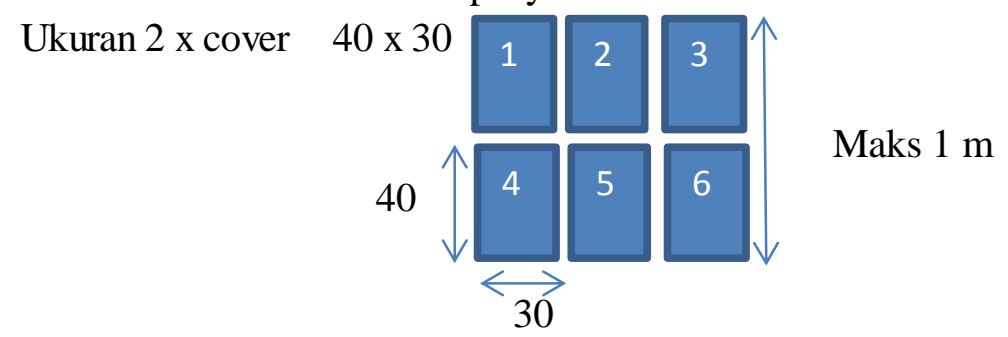

Penyusunan cover dalam 1 palet dapat disusun 6 baris cover. Misalkan untuk jenis lks Pkn dalam 1 palet dapat disusun jenis lks Pkn dari kelas $1-6$. Berikut merupakan kebutuhan ruang untuk cover:

Tabel 8. Data Kebutuhan Ruang Produk Setengah Jadi Cover

\begin{tabular}{|c|c|c|c|c|c|c|c|c|}
\hline Penerbit & \multicolumn{2}{|c|}{ Kebutuhan (Pallet) } & Tingkat & $\begin{array}{c}\text { Kebutuhan } \\
\text { Lebar Ruangan } \\
\text { Teoritis (m) } \\
\end{array}$ & $\begin{array}{c}\text { Kebutuhan } \\
\text { Lebar Ruangan } \\
\text { Aktual (m) }\end{array}$ & $\begin{array}{c}\text { Allowanc } \\
\text { e (m) }\end{array}$ & $\begin{array}{c}\text { Lebar } \\
\text { Ruang } \\
(\mathrm{m})\end{array}$ & $\begin{array}{c}\text { Panjang } \\
\text { Ruang } \\
\text { (m) }\end{array}$ \\
\hline \multirow{3}{*}{ Indonesia Jaya } & \multirow{3}{*}{3} & 1 & SD & 0,5 & 1 & 0,5 & 1,5 & 2,5 \\
\hline & & 1 & SMP & 0,5 & 1 & 0,5 & 1,5 & 2,5 \\
\hline & & 1 & SMA & 0,5 & 1 & 0,5 & 1,5 & 2,5 \\
\hline $\mathrm{TM}$ & \multicolumn{2}{|c|}{1} & SD & 0,5 & 1 & 0,5 & 1,5 & 2,5 \\
\hline $\mathrm{HB}$ & \multicolumn{2}{|c|}{1} & SMP & 0,5 & 1 & 0,5 & 1,5 & 2,5 \\
\hline $\mathrm{BP}$ & \multicolumn{2}{|c|}{1} & SD & 0,5 & 1 & 0,5 & 1,5 & 2,5 \\
\hline & & & & & & Total & 9 & \\
\hline
\end{tabular}

c. Kebutuhan Aisle (Tempat untuk Jalannya Forklift)

Dari hasil wawancara, perusahaan menginginkan allowance untuk lebar aisle minimal $40 \%$ agar forklift bisa bermanuver dengan lancar.

Panjang forklift adalah 3,1 m dan lebarnya 1,3 m.

Sehingga dimensi terpanjang forklift adalah:

$$
d=\sqrt{3,1^{2}+1,3^{2}}=3,289 \mathrm{~m}
$$

Allowance $=40 \%$ × 3,289 $\mathrm{m}=1,315 \mathrm{~m}$

Total lebar aisle forklift $=3,29+1,32=4,61=5 \mathrm{~m}$

\section{Layout Setelah Usulan}

Berikut merupakan layout keseluruhan setelah dilakukan perbaikan:

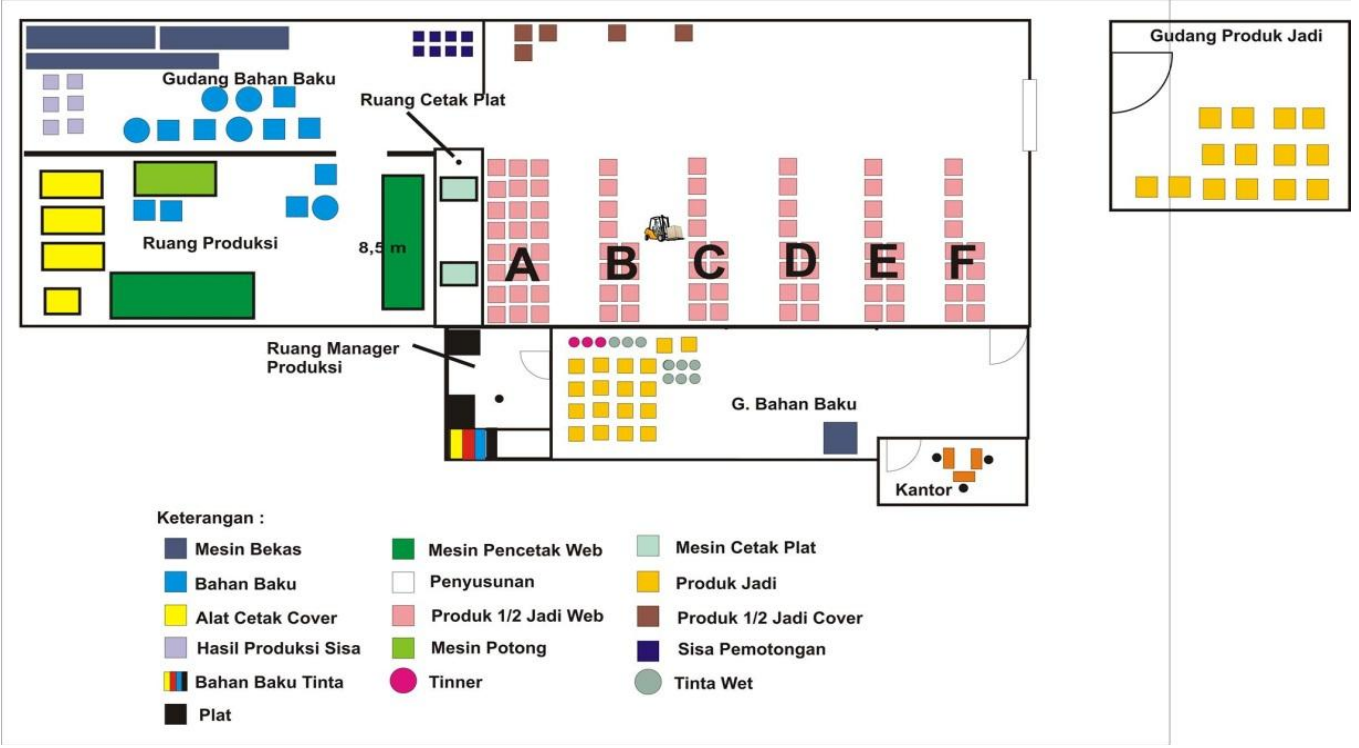

Gambar 9. Layout Usulan 
Gambar di atas menunjukkan kondisi pabrik setelah dilakukan perbaikan berdasarkan usulan yang diajukan. Kotak warna pink yang menunjukkan barang $1 / 2$ jadi yang sebelumnya ditempatkan secara sembarangan kini ditata secara rapi sesuai dengan jenis dan perusahaan yang memesannya. Produk ABC berasal dari perusahaan Indonesia Jaya, produk D berasal dari perusahaan TM, produk $\mathrm{E}$ dari perusahaan $\mathrm{HB}$, dan produk $\mathrm{F}$ berasal dari perusahaan BP. Sebelum dilakukan penataan, semua produk bercampur baur dan terletak secara sembarangan, bahkan ada yang berada di line produksi. Hal ini tentu akan mengganggu proses produksi dan proses material handling produk itu sendiri dan produk lainnya. Perbaikan ini menggunakan metode class based storage yaitu sebuah metode menggunakan pendekatan jenis dalam melakukan tata letak. Dengan dikelompokkan berdasarkan perusahaan pemesan maka dapat mempermudah dalam pencarian produk.

Berdasarkan perbaikan tata letak gudang produk setengah jadi, dapat diketahui kapasitas maksimum gudang untuk penyimpanan produk setengah jadi.

Ukuran Gudang $\quad=40 \mathrm{~m} \times 16 \mathrm{~m}$

Ukuran Palet $\quad=1 \mathrm{~m} \times 1 \mathrm{~m}$

Ukuran aisle $\quad=5 \mathrm{~m} \mathrm{x} 40 \mathrm{~m}$

Jadi maksimum palet untuk produk web (isi) yang dapat disimpan dalam gudang sebesar $8 \times 40=320$ palet dan produk cover sebesar $2 \times 40=80$ palet. Penataan ini tanpa menggunakan space. Sesuai aturan, karena harus diurutkan sesuai jenisnya, maka dibedakan antar jenis penerbit dengan memberi space sebesar $1 \mathrm{~m}$. Penambahan space $1 \mathrm{~m}$ akan mengurangi kapasitas palet sebesar 8 palet sehingga setiap penambahan customer/penerbit maka terjadi pengurangan kapasitas 8 palet. Begitu pula dengan kapasitas palet untuk produk cover. Setiap penambahan penerbit akan mengurangi kapasitas palet sebesar 2 palet.

4. Perhitungan Layout Perbaikan

a. Perhitungan Jarak perpindahan material

Dengan menganggap titik pada pojok kiri belakang gudang sebagai titik $(0,0)$, maka koordinat titik pusat dari masing-masing blok penyimpanan adalah titik berat $(\mathrm{x}, \mathrm{y})$ dari blok tersebut. Karena tidak ada material yang mempunyai lokasi penyimpanan lebih dari satu area, maka titik pusat tidak ditentukan berdasarkan gabungan dari titik berat area penyimpanan.

Tabel 11. Koordinat Akhir Titik Pusat Area

\begin{tabular}{|l|l|l|}
\hline Item & Blok Penyimpanan & $\begin{array}{l}\text { Koordinat Titik Pusat } \\
\text { Gabungan }(\mathrm{x}, \mathrm{y}) \mathrm{m}\end{array}$ \\
\hline Indojaya-SD & $\mathrm{A}$ & $(11 / 2,4)$ \\
\hline Indojaya-SMP & B & $(6,4)$ \\
\hline Indojaya-SMA & C & $(11,4)$ \\
\hline TM-SD & D & $(16,4)$ \\
\hline HB-SM & E & $(21,4)$ \\
\hline BP SD & F & $(26,4)$ \\
\hline
\end{tabular}

Untuk mengetahui jarak perpindahan adalah dengan cara mengalikan frekuensi perpindahan dan jarak blok penyimpanan dari (I/O point). Jarak perpindahan dihitung dengan menggunakan metode rectilinier. Berikut merupakan hasil perhitungan jarak adalah sebagai berikut:

Tabel 12.Hasil Perhitungan Jarak Perpindahan Material

\begin{tabular}{|l|l|l|l|}
\hline Item & $\begin{array}{l}\text { Frekuensi } \\
\text { perpindahan }\end{array}$ & $\begin{array}{l}\text { Jarak Penyimpanan } \\
(\mathrm{m})\end{array}$ & Total Jarak (m) \\
\hline Indojaya-SD & 10 & 45 & 450 \\
\hline Indojaya-SMP & 10 & 40 & 400 \\
\hline Indojaya-SMA & 10 & 35 & 350 \\
\hline TM-SD & 10 & 30,5 & 305 \\
\hline HB-SM & 10 & 25,5 & 255 \\
\hline BP SD & 10 & 20,5 & 205 \\
\hline Total & 60 & & 1975 \\
\hline
\end{tabular}


Berdasarkan hasil perhitungan didapatkan bahwa tital jaraka perpindahaan perbulannya sebesar $1975 \mathrm{~m}$

\section{Perhitungan OMH (Ongkos Material Handling)}

Pada perhitungan Material Handling (OMH) digunakan asumsi:

a. Perhitungan $\mathrm{OMH}$ hanya untuk aktivitas pengambilan produk setengah jadi

b. Kecepatan saat pemakaian peralatan untuk material handling tetap, baik ketika forklift dalam posisi kosong atau berisi)

c. Nilai sisa peraltan material handling ketika dijual karena umur ekonominya sudah habis sebesar Rp 20.000.000,00.

Biaya-biaya tersebut antara lain:

a. Biaya Peralatan (Fixed Cost)

Peralatan material handling yang digunakan adalah forklift dengan spesifikasi:

Spesifikasi Forklift

\begin{tabular}{|l|l|}
\hline Spesifikasi Forkloft & \\
\hline Merk & Toyota Tonero \\
\hline Harga Pembelian (P) & Rp 250.0000.000,00 \\
\hline Umur Ekonomis (N) & 10 Tahun \\
\hline Nilai Sisa (S) & Rp 25.000.000,00 \\
\hline Biaya Maintenance & Rp5.000.0000,00//tahun \\
\hline Jenis Bahan Bakar & Solar \\
\hline Penggunaan Bahan Bakar & 1 liter/km \\
\hline
\end{tabular}

b. Biaya Bahan bakar (Variable Cost)

Operasional forklift menghabiskan biaya sebesar:

Biaya bahan bakar = Kebutuhan solar $(l)$ per meter $\mathrm{x}$ harga solar saat ini

Biaya bahan bakar (Variable Cost)

Tempat penyimpanan dipisahkan berdasarkan jenis produk

c. Perhitungan Depresiasi (Fixed Cost)

$$
\begin{aligned}
\text { Dt } & =\frac{p-s}{N}=\frac{\text { harga forklift }- \text { nilai sisasi }}{10} \\
& =\frac{250.000 .000-25.000 .000}{10} \\
& =\operatorname{Rp} 22.500 .000,00
\end{aligned}
$$

d. Biaya Mesin

Biaya mesin

$=$ fixed cost $($ Depresiasi + Biaya Maintenance $)+$ Variable Cost (Biaya Bahan Bakar)

$=(22.500 .000+5.000 .0000)+(1975 \times 12 \times 6700 \times 1)$

$=27.500 .000+158.790 .000$

$=186.290 .000$

Sehingga biaya mesin dalam satu tahun sebesar186.290.000 rupiah.

e. Biaya operator Forklift

Operator yang ada masing-masing 1 orang setiap shift berarti ada 3 operator. Upah pekerjanyanya sesuai UMR Kota Karanganyar yaitu sejumlah Rp 1.500.000,00 per orang dalam satu bulan. Jika dihitung maka per hari dibayar sebesar Rp 62.500 dan mereka bekerja selama 8 jam. Maka perjamnya dibayar rata-rata sebesar Rp 7.812,00. Proporsi pemindahan forklift adalah $30 \%$ x 24 jam $=7,2$ jam. Dengan jarak perpindahannya sebesar $1975 \mathrm{~m}$ per bulan maka per hari per pindahannya adalah sebesar 82,29 m, sehingga:

Kecepatan forklift (V) 
$=\frac{\text { jarak perpinda han }(t)}{\text { waktu }(w)}=\frac{82,29 \mathrm{~m}}{7,2 \mathrm{jam}}=11,43 \mathrm{~m} / \mathrm{jam}$

Biaya Operator

= biaya/jam x waktu operasi perpindahan forklift

$=\operatorname{Rp} 7.812,00\left(\frac{x}{v}\right)$

f. Perhitungan OMH Usulan

$\mathrm{OMH}=$ Biaya Mesin + Biaya Operator

$=(22.500 .000+5.000 .0000)+(1975 \times 12 X 6700 X 1)+\operatorname{Rp} 7.812,00\left(\frac{1975 \times 12}{11,43}\right)$

$=\mathrm{Rp} 186.290 .000+\mathrm{Rp} 7.812,00 \times 2.073,49$

$=\operatorname{Rp} 186.290 .000+\operatorname{Rp} 16.198 .104,00$

$=\mathrm{Rp} 202.488 .104,00$ per tahun

g. Perhitungan Ongkos material handling $(\mathrm{OMH})$ pada lay out awal

Pada lay out awal tidak dilakukan perhitungan karena lokasinya yang terlalu acak. Sehingga perhitungan hanya dilakukan pada lay out usulan. Sedangkan untuk layout awal hanya berdasarkan hasil observasi kami dengan menggunakan teknik wawancara yaitu kira-kira sebesar Rp. 300.000.000,00

\section{Simpulan}

Berdasarkan hasil perhitungan dan analisis yang dilakukan dapat diketahui alternatif yang layak untuk mengatasi permasalahan keterlambatan pengiriman barang adalah dengan melakukan pembelian trolley. Diketahui biaya yang harus dikeluarkan apabila melakukan pengadaan trolley adalah sebesar Rp 6.946,67 untuk OMH dan untuk perhitungan NPV adalah Rp 43.752.394,91.

Dengan melakukan pengadaan trolley sebagai alat bantu untuk memindahkan barang berdampak postif yaitu proses perpindahan lebih efektif dan efisien. Dengan demikian dapat mempercepat proses penanganan material di gudang, sehingga dapat meminimalkan keterlambatan pengiriman yang terjadi di PT. TIKI Cabang Solo.

\section{Daftar Pustaka}

Bloomberg, D. J. (2002). Logistics 4th Edition. Prentice Hall International Inc, Great Britain.

Bowersox, D. J. (2013). Management Logistics International Edition. Graw Hill, Singapore.

Demet, L. (2012). Impact of workplare quality on employee's productivity: case study of a bank in

Turkey PhD candidate, Okan University, Turkey. Journal of Business, Economics \& Finances, Vol 1, No.1, pp. 38-49.

Giemenez, C. (2006). Logistics intergration processes in the food industry, International Journal of Physical Distribution and Logistics Management, Vol.36

Hansen, Don R, dan Maryanne Mowen. (2007). Management Accounting $8^{\text {th }}$ Edition, Mc Graw Hill, Dallas.

Komara, J. (2014) Studi deskriptif aktivitas inbound outbond logistik pada UD Sumber Baru di Jember. Jurnal Ilmiah Mahasiswa Universitas Surabaya, Vol.3, No.1

Rahadian, F. G. (2011). Model Rute Transportasi Milkrun Dari Pengadaan Komponen Pada Pabrik Kendaraan Bermotor Dan Analisa Kelayakan Investasi Pengadaan Armada Pengangkutan. (Studi Kasus PT ISI). Jakarta: Departemen Teknik Industri Fakultas Teknik Universitas Indonesia.

Setiadi, N. (2014). Studi deskriptif aktifitas logistik inbound outbound pada PT Sinar Cahaya Cemerlang di Surabaya. Jurnal Ilmiah Mahasiswa Universitas Surabaya, Vol.3, No.2

W.E. Biles, J. U. (2006). Material Handling, Mechanical Engineers Handbook 3rd Edition. 